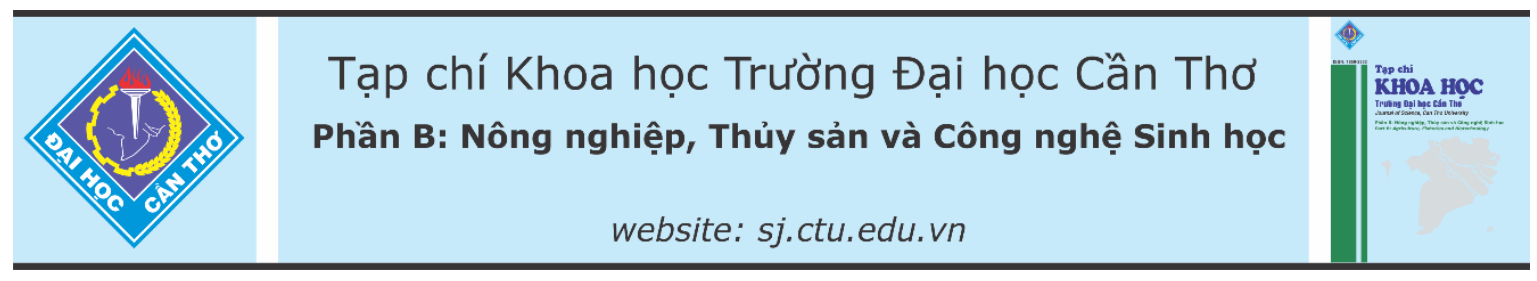

DOI:10.22144/ctu.jvn.2021.152

\title{
KHẢ NĂNG HÒA TAN LÂN VÀ ĐỐI KHÁNG VỚI NÁM Fusarium solani CỦA DÒNG NẤM Aspergillus niger H4.7 Ở ĐIỀU KIỆN PHÒNG THÍ NGHIẸM
}

\author{
Châu Thị Anh Thy, Đặng Thị Yến Nhung và Nguyễn Khởi Nghĩa* \\ Khoa Nông nghiệp, Truờng Đại học Cần Tho \\ *Nguoòi chịu trách nhiệm về bài viết: Nguyễn Khởi Nghĩa (email: nknghia@ctu.edu.vn)
}

\section{Thông tin chung:}

Ngày nhận bài: $27 / 05 / 2021$

Ngày nhận bài sủa: 26/06/2021

Ngày duyệt đăng: 29/10/2021

\section{Title:}

Capacity in phosphorous solubilization and antagonism against the Fusarium solani fungal strain of the fungus Aspergillus niger H4.7 under the laboratory condition

\section{Tù khóa:}

Aspergillus niger, đối kháng, Fusarium solani, lân, nấm hòa tan lân

\section{Keywords:}

Antagonistic, Aspergillus niger, Fusarium solani, phosphorous, phosphorous solubilizing fungi

\section{ABSTRACT}

The main objective of this study was to evaluate the capacity in phosphorous solubilization under a number of different environmental conditions and antagonism against the Fusarium solani fungal strain of the fungus Aspergillus niger H4.7 (H4.7), a well organic material decomposer, isolated from the agricultural soil in Soc Trang province under the laboratory condition. The experiments for testing a number of different environmental conditions including $\mathrm{pH}, \mathrm{NaCl}$ salt concentration and the solubilizing ability toward two insoluble phosphate forms $\left(\mathrm{FePO}_{4}\right.$ and $\mathrm{AlPO}_{4}$ ) were carried out in NBRIP liquid culture medium while the antagonistic activity test of the strain $H 4.7$ against the plant pathogenic fungus, Fusarium solani was conducted on PDA medium. The results showed that the fungal strain $H 4.7$ gave the best result in phosphate solubilization and in biomass formation under the condition of cultural medium like $\mathrm{pH}=7$ and $0 \% \mathrm{NaCl}$. Moreover, $\mathrm{Ca}_{3}\left(\mathrm{PO}_{4}\right)_{2}$ was solubilized the most followed by $\mathrm{AlPO}_{4}$ and $\mathrm{FePO}_{4}$. Besides, results also revealed that the fungal strain $\mathrm{H} 4.7$ also had a good function in resisting the plant pathogenic fungus, Fusarium solani causing plant root rot diseases, especially, at 5 days of incubation, the antagonistic performance of the fungal strain $\mathrm{H} 4.7$ was achieved at $49.2 \%$.

\section{TÓM TẮT}

Mục tiêu của nghiên cứu nhằm khảo sát khả năng hòa tan lân duoói một số điều kiện môi truờng khác nhau và đối kháng với nấm bệnh Fusarium solani của dòng nấm Aspergillus niger H4.7 (H4.7) được phân lập tù đất nông nghiệp ở tỉnh Sóc Trăng ở điều kiện phòng thi nghiệm. Việc khảo sát khả năng hòa tan lân duoới các điều kiện môi truờng gồm $\mathrm{pH}$, nồng độ muối $\mathrm{NaCl}$ và các dạng lân khó tan khác $\left(\mathrm{FePO}_{4}\right.$ và $\left.\mathrm{AlPO}_{4}\right)$ được thực hiện trong môi truờng NBRIP lỏng, trong khi thí nghiệm khảo sát khả năng đối kháng của dòng nấm H4.7 với dòng nấm Fusarium solani gây bệnh hai cây trồng được thực hiện trên môi truờng PDA. Kết quả nghiên cứu cho thấy dòng nấm H4.7 có khả năng hòa tan lân tốt trong môi trường nuôi cấy có $\mathrm{pH}=7$, không bổ sung $\mathrm{NaCl}$ và hòa tan tốt các dạng lân khó tan theo thư tụ $\mathrm{Ca}_{3}\left(\mathrm{PO}_{4}\right)_{2}>\mathrm{FePO}_{4}>\mathrm{AlPO}_{4}$. Ngoài ra, dòng nấm này còn có khả năng đối kháng tốt với dòng nấm Fusarium solani, đặc biệt ở thời điểm 5 ngày sau bố trí với hiệu suất đối kháng đạt 49,2\%. 


\section{GIỚI THIỆ}

Lân là một nguyên tố dinh dưỡng thiết yếu cần thiết cho sự sinh trưởng và phát triển của cây trồng (Reena et al., 2013). Lân đóng vai trò quan trọng trong tất cả những tiến trình cũng như hoạt động sinh lý, sinh hóa và chuyển hóa vật chất trong cây như: sự phân chia tế bào, phát triển hệ thống rễ, sử dụng nguồn carbohydrate, quang hợp, chuyển hóa năng lượng, sinh tổng hợp tế bào, hô hấp (Khan et al., 2010). Cây trồng chỉ hấp thu lân dạng ion hoà tan (Pi) như: $\mathrm{HPO}_{4}{ }^{2-}$ hoặc $\mathrm{H}_{2} \mathrm{PO}_{4}^{-}$(Malboobi et al., 2009). Lượng lân dễ tiêu tự nhiên trong môi trường đất thường rất thấp, phần lớn ở dạng đá, khoáng và quặng khó tan (Goldstein, 1994). Khi cây trồng thiếu lân sẽ dẫn đến triệu chứng lá nhỏ, có màu nâu, thân cây yếu, dễ bị gãy và chậm phát triển (Kannaiyan et al., 2004). Sự tích lũy lân trong đất là do sự hấp phụ lân trên bề mặt keo đất và sự kết tủa lân với các cation trong đất, đặc biệt là với sắt, nhôm và calcium. Vi sinh vật hòa tan lân có vai trò quan trọng trong việc khắc phục sự thiếu lân trong đất cho cây trồng hấp thu (Ashrafuzzaman et al., 2009).

Trong số vi khuẩn trong đất có khả năng hòa tan lân, chi Bacillus, Pseudomonas, Rhizobium, Enterobacter là những chi vi khuẩn có khả năng hòa tan lân mạnh nhất đã được nghiên cứu bởi Ghosh et al. (2011), Halder et al. (1990), Nguyễn Hữu Hiệp và Hà Đức Danh (2009), Sharma et al. (2011). Bên cạnh vi khuẩn, nấm cũng có vai trò rất quan trọng trong việc hòa tan lân bị cố định trong đất, tuy nhiên, phụ thuộc rất nhiều vào tầng đất và điều kiện dinh dưỡng (Nahas, 1996). Nấm hòa tan lân rất đa dạng về mặt di truyền, trong đó, chi nấm Aspergillus, Trichoderma, Fusarium và Penicillium là những chi nấm phổ biến nhất có khả năng hòa tan lân bị cố định trong đất (Asea et al., 1988; Flavia et al., 2012). Theo Sudhakara et al. (2002), ba dòng nấm phân lập Aspergillus tubingensis và hai dòng nấm Aspergillus niger cho kết quả hòa tan lân có nguồn gốc từ đá phosphate rất cao. Trong đó, dòng nấm Aspergillus tubingensis AT1 có khả năng hòa tan lân cao nhất đạt $89 \%$ khi nuôi trong môi trường có chứa $2 \%$ đá phosphate. Ba dòng nấm này có tiềm năng rất cao trong việc sử dụng như phân bón sinh học và phòng trừ sinh học nấm Fusarium oxysporum trong sản xuất măng tây hữu cơ (Ruangsanka, 2014). Công bố của Phạm Thị Ngọc Lan và Hoàng Dương Thu Hương (2014) đã phân lập và tuyển chọn được hai chủng nấm mốc hòa tan lân vô cơ từ đất rừng ngập mặn ở Thừa Thiên Huế và được định danh như Aspergillus oryzae M33 và Aspergillus japonicas M72. Nghiên cứu của Trần Thị Phương Thu và Nguyễn Khởi Nghĩa (2018) cũng đã phân lập và tuyển chọn được hai dòng nấm Penicillium funiculosum $\mathrm{B} 1$ và Aspergillus tubingensis $\mathrm{B} 10$ hoà tan lân lần lượt đạt $2.104 \mathrm{mg} / \mathrm{L}$ và $2.618 \mathrm{mg} / \mathrm{L}$ sau 3 và 4 ngày thí nghiệm.

Dòng nấm Aspergillus niger H4.7 được phân lập từ đất nông nghiệp ở tỉnh Sóc Trăng sử dụng trong nghiên cứu này có khả năng hòa tan lân $\mathrm{Ca}_{3}\left(\mathrm{PO}_{4}\right)_{2}$ trong môi trường NBRIP lỏng sau 6 ngày nuôi cấy (NNC) đạt $2.046 \mathrm{mg} / \mathrm{L} \mathrm{P}_{2} \mathrm{O}_{5}$. Tuy nhiên, khả năng hòa tan lần của dòng nấm này dưới một số điều kiện môi trường nuôi cấy khác nhau và khả năng đối kháng với dòng nấm gây bệnh thối rễ trên cây cam sành Fusarium solani của dòng nấm này vẫn chưa được khảo sát. Vì vậy, nghiên cứu này được thực hiện nhằm mục tiêu: (1) Khảo sát một số đặc tính sinh lý và sinh hóa của dòng nấm hòa tan lân Aspergillus niger $\mathrm{H} 4.7$ ở điều kiện phòng thí nghiệm và (2) Khảo sát khả năng đối kháng với dòng nấm Fusarium solani gây bệnh hại cây trồng của dòng nấm hòa tan lân $\mathrm{H} 4.7$ ở điều kiện phòng thí nghiệm. Kết quả nghiên cứu là cơ sở để ứng dụng dòng nấm có khả năng hòa tan lân vào canh tác nông nghiệp nhằm sử dụng hiệu quả và tiết kiệm lượng phân bón lân hóa học, đồng thời giúp tăng sinh trưởng và năng suất cây trồng.

\section{VÂTT LIỆU VÀ PHƯƠNG PHÁP NGHIÊN CÚU}

\subsection{Vật liệu nghiên cứu}

Dòng nấm Aspergillus niger H4.7 (H4.7) được phân lập từ đất nông nghiệp ở tỉnh Sóc Trăng (Quách Thị Trúc Ly, 2019). Dòng nấm này được lưu giữ tại Phòng thí nghiệm Sinh học Đất, Bộ môn Khoa học Đất, Khoa Nông nghiệp, Trường Đại học Cần Thơ.

Dòng nấm gây bệnh thối rễ cây cam sành Fusarium solani được phân lập và bảo quản tại phòng thí nghiệm Sinh học Đất, Bộ môn Khoa học Đất, Khoa Nông nghiệp, Trường Đại học Cần Thơ.

Môi trường PDA dùng để nuôi cấy nấm. Thành phần môi trường PDA trong $1 \mathrm{~L}$ dung dịch gồm: extract potatoes, $4 \mathrm{~g}$; dextrose, $20 \mathrm{~g}$ và agar, $15 \mathrm{~g}$ hòa tan đều trong $1 \mathrm{~L}$ nước cất và sau đó tiệt trùng $121^{\circ} \mathrm{C}$ trong 20 phút.

Môi trường NBRIP lỏng dùng để đánh giá khả năng hòa tan lân của nấm. Thành phần môi trường NBRIP lỏng trong $1 \mathrm{~L}$ dung dịch gồm: glucose $10 \mathrm{~g}$, $\mathrm{Ca}_{3}\left(\mathrm{PO}_{4}\right)_{2} 5 \mathrm{~g}, \mathrm{MgSO}_{4} 0,25 \mathrm{~g}, \mathrm{KCl} 0,2 \mathrm{~g},\left(\mathrm{NH}_{4}\right)_{2} \mathrm{SO}_{4}$ $0,1 \mathrm{~g}, \mathrm{MgCl}_{2} \cdot 6 \mathrm{H}_{2} \mathrm{O} 5 \mathrm{~g}$, hòa tan đều trong $1 \mathrm{~L}$ nước cất và sau đó tiệt trùng $121^{\circ} \mathrm{C}$ trong 20 phút. 
2.2. Khảo sát ảnh hưởng của một số điều kiện môi trường nuôi cấy khác nhau lên khả năng hòa tan lân và sinh khối của dòng nấm H4.7 ở điều kiện phòng thí nghiệm

2.2.1. Thí nghiệm đánh giá ảnh huởng của các múc pH môi truờng nuôi cấy khác nhau lên khả năng hòa tan lân của dòng nấm H4.7

- Muc tiêu: Nhằm tìm ra mức $\mathrm{pH}$ môi trường nuôi cấy phù hợp để giúp dòng nấm H4.7 hòa tan lân tốt nhất trong môi trường nuôi cấy lỏng ở điều kiện phòng thí nghiệm.

_ * Chuẩn bi nguồn nấm: Trước khi tiến hành bố trí thí nghiệm, dòng nấm $\mathrm{H} 4.7$ được nuôi cấy trên môi trường PDA trong 3 ngày ở điều kiện phòng thí nghiệm để dòng nấm này gia tăng sinh khối hệ sợi nấm để chuẩn bị nguồn cho thí nghiệm (a).

- Bố trí thí nghiệm: Dùng pasteur pipet có đường kính $0,6 \mathrm{~cm}$ đã tiệt trùng để cắt khối agar có sợi nấm đang phát triển tốt đã chuẩn bị sẵn ở mục a và cho 3 khối agar chứa nấm vào bình tam giác 100 $\mathrm{mL}$ chứa sẵn $50 \mathrm{~mL}$ môi trường NBRIP lỏng đã khử trùng và được hiệu chỉnh về 4 mức $\mathrm{pH}$ môi trường nuôi cấy khác nhau tương ứng với 4 nghiệm thức thí nghiệm gồm: $3,5,7$ và 9 . Mỗi nghiệm thức có 3 lặp lại tương ứng với 3 bình tam giác. Nghiệm thức đôi chứng tương ứng với từng mức $\mathrm{pH}$ môi trường khác nhau được thực hiện tương tự nhưng không chủng nấm vào. Các bình tam giác được đặt trên máy lắc tròn với tốc độ 120 vòng/phút và ở điều kiện môi trường của phòng thí nghiệm. Hàm lượng lân hòa tan trong môi trường nuôi cấy được xác định sau 1 , $3,5,7,10$ và 12 ngày bố trí thí nghiệm. Phân tích lân hòa tan trong môi trường nuôi cấy lỏng bằng phương pháp hiện màu Molybdate (Murphy \& Riley, 1962; Novozamsky et al., 1984). Mẫu được đo trên máy so màu quang phổ (Spectrometer Thermo Scientific, Multiskan Spectrum) ở bước sóng $880 \mathrm{~nm}$. Đồng thời, sinh khối nấm cũng được thu nhận tại thời điềm 12 ngày bố trí thí nghiệm. Xác định sinh khối khô của nấm trong bình tam giác nuôi cấy lỏng bằng phương pháp cân trọng lượng khô: Toàn bộ môi trường nuôi cây lỏng gồm cả sinh khối nấm được cho qua phểu thủy tinh có chứa giấy lọc đặt lên trên và phểu được đặt trên beaker. Để khô tự nhiên trong 10 phút, sau đó đặt giấy lọc chứa sinh khối nấm vào trong tủ sấy ở nhiệt độ $105^{\circ} \mathrm{C}$ trong 24 giờ để xác định sinh khối khô của nấm.

\subsubsection{Thí nghiệm đánh giá ảnh hưởng của nồng độ muối NaCl khác nhau của môi truờng nuôi cấy lên khả năng hòa tan lân của dòng nấm $H 4.7$}

- Muc tiêu: Nhằm tìm ra nồng độ muối $\mathrm{NaCl}$ thích hợp của môi trường nuôi cấy mà dòng nấm H4.7 có khả năng hòa tan lân tốt nhất trong môi trường nuôi cấy lỏng ở điều kiện phòng thí nghiệm và đồng thời đánh giá xem ngưỡng chịu mặn của dòng nấm nấm H4.7. Bên cạnh đó, nghiên cứu này còn hướng đến việc ứng dụng dòng nẩm H4.7 trong canh tác cây trồng trên nền đất nhiễm mặn nhằm giúp cung cấp lượng lân hữu dụng vốn đã bị bất động trong đất cho cây trồng sinh trưởng và phát triển tốt.

- Chuẩn bị nguồn nấm: Tương tự như mục a.

- Bố trí thí nghiệm: Toàn bộ qui trình và cách bố trí thí nghiệm được thực hiện tương tự như thí nghiệm đánh giá ảnh hưởng của $\mathrm{pH}$ môi trường nuôi cấy lên khả năng hòa tan lân của dòng nấm H4.7 ở mục 2.2.1. Tuy nhiên, môi trường NBRIP lỏng trong thí nghiệm này có bổ sung 4 nồng độ $\mathrm{NaCl}$ khác nhau: $0,1,5$ và $10 \%$. pH môi trường NBRIP nuôi cấy được hiệu chỉnh dựa vào kết quả thí nghiệm đánh giá $\mathrm{pH}$ môi trường ở mục 2.2.1. Mỗi nghiệm thức có 3 lặp lại tương ứng với 3 bình tam giác. Hàm lượng lân hòa tan trong môi trường nuôi cấy được xác định sau $1,3,5,7,10$ và 12 ngày bố trí thí nghiệm. Phương pháp phân tích hàm lượng lân hòa tan trong môi trường nuôi cấy lỏng bằng phương pháp hiện màu Molybdate và phương pháp xác định sinh khối khô của nấm được thực hiện như mục 2.2.1.

\subsubsection{Thi nghiệm đánh giá khả năng hòa tan hai dạng lân khó tan khác $\left(\mathrm{FePO}_{4}\right.$ và $\left.\mathrm{AlPO}_{4}\right)$ của dòng nấm H4.7 trong môi truoòng nuôi cấy lỏng ở điều kiện phòng thí nghiệm}

- Muc tiêu: Nhằm đánh giá khả năng hòa tan lân có nguồn gốc từ lân khó tan $\mathrm{FePO}_{4}$ và $\mathrm{AlPO}_{4}$ trong môi trường nuôi cấy lỏng ở điều kiện phòng thí nghiệm của dòng nấm $\mathrm{H} 4.7$. Nghiên cứu này sử dụng hai nguồn lân khó tan $\mathrm{FePO}_{4}$ và $\mathrm{AlPO}_{4}$ bởi vì lân bị liên kết với $\mathrm{Fe}$ và $\mathrm{Al}$ trong đất rất phổ biến ở khu vực Đồng bằng sông Cửu Long, đặc biệt là vùng đất phèn. Vì vậy, việc sử dụng dòng nấm $\mathrm{H} 4.7$ có khả năng hòa tan lân khó tan do bị cố định bởi lượng Fe và $\mathrm{Al}$ trong đất phèn có một ý nghĩa hết sức quan trọng trong việc giúp cây trồng vượt qua bất lợi về sự thiếu hụt lân. 
- Chuẩn bị nguồn nấm: Tương tự như mục a.

- Bố trí thí nghiệm: Toàn bộ qui trình và cách bố trí thí nghiệm được thực hiện tương tự như thí nghiệm đánh giá ảnh hưởng của $\mathrm{pH}$ môi trường nuôi cấy lên khả năng hòa tan lân của dòng nấm $\mathrm{H} 4.7$ ở mục 2.2.1. Tuy nhiên, môi trường NBRIP lỏng trong thí nghiệm này được bố trí với ba dạng lân khác nhau: $\mathrm{Ca}_{3}\left(\mathrm{PO}_{4}\right)_{2}, \mathrm{FePO}_{4}$ và $\mathrm{AlPO}_{4}$ (môi trường NBRIP lỏng bổ sung $0,5 \%$ nguồn lân khó tan). Môi trường NBRIP lỏng chứa ba dạng lân khác nhau được hiệu chỉnh dựa vào kết quả thí nghiệm đánh giá $\mathrm{pH}$ ở mục 2.2 .1 và nồng độ muối $\mathrm{NaCl}$ ở mục 2.2.2. Mỗi nghiệm thức có 3 lặp lại tương ứng với 3 bình tam giác. Hàm lượng lân hòa tan trong môi trường nuôi cấy được xác định sau $1,3,5,7,10$ và 12 ngày bố trí thí nghiệm. Phương pháp phân tích hàm lượng lân hòa tan trong môi trường nuôi cấy lỏng bằng phương pháp hiện màu Molybdate và phương pháp xác định sinh khối khô của nấm được thực hiện như mục 2.2.1.

\subsection{Thí nghiệm khảo sát khả năng đối kháng với dòng nấm Fusarium solani gây bệnh thối rễ cây cam sành của dòng nấm hòa tan lân H4.7 ờ điều kiện phòng thí nghiệm}

\subsubsection{Chuẩn bị nguồn nấm}

Trước khi tiến hành bố trí thí nghiệm, cả hai dòng nấm $\mathrm{H} 4.7$ và dòng nấm Fusarium solani được nuôi cấy trước trên đĩa petri chứa môi trường PDA trong 3 ngày trong điều kiện phòng thí nghiệm để hai dòng nấm này gia tăng sinh khối hệ sợi nấm để chuẩn bị nguồn cho thí nghiệm.

\subsubsection{Bố trí thí nghiệm}

Việc khảo sát khả năng đối kháng với dòng nấm Fusarium solani gây bệnh thối rễ trên cây trồng được thực hiện theo phương pháp của Komy et al. (2015). Cách thực hiện như sau: Trước tiên, dùng bút lông chia đĩa môi trường ra làm 3 phần đều nhau; tiếp đó, dùng pasteur pitette đã tiệt trùng có đường kính $0,6 \mathrm{~cm}$ để cắt khối agar chứa hệ sợi của hai dòng nấm $\mathrm{H} 4.7$ và dòng nấm Fusarium solani gây bệnh cây trồng đang phát triển tốt đã chuẩn bị sẵn, lần lượt đặt hai khối agar chứa hai dòng nấm này vào vị trí chính giữa của $1 / 3$ thứ nhất và vào vị trí chính giữa của $1 / 3$ thứ hai trên đĩa petri chứa môi trường nuôi cấy PDA (Hình 1); sau cùng, dán parafilm bên ngoài đĩa petri đã chứa nấm và đặt vào tủ ủ cho nấm phát triển trong 7 ngày. Sự phát triển của dòng nấm Fusarium solani gây bệnh cây trồng trên đĩa petri được đo bán kính tản nấm sau: $1,3,5$ và 7 ngày sau khi nuôi cấy ở cả nghiệm thức thí nghiệm và nghiệm thức đối chứng. Tính hiệu suất đối kháng (\%) của dòng nấm H4.7 theo công thức 2.1. Thí nghiệm được thực hiện với 3 lần lặp lại cho mỗi nghiệm thức và một lặp lại tương ứng với 1 đĩa petri. Nghiệm thức đối chứng chỉ chứa dòng nấm H4.7 hoặc dòng nấm Fusarium solani.

Hiệu suất đối kháng của nấm (Percent inhibition - PI) được tính theo công thức sau:

$$
\mathrm{PI}(\%)=(\mathrm{R}-\mathrm{r}) / \mathrm{R} \times 100 \text { (2.1) }
$$

Trong đó: PI: Hiệu suất đối kháng của dòng nấm $(\%)$.

R: Bán kính tản nấm của dòng nấm gây bệnh ở nghiệm thức đối chứng $(\mathrm{mm})$

r: Bán kính tản nấm của dòng nấm gây bệnh ở nghiệm thức thí nghiệm (mm)

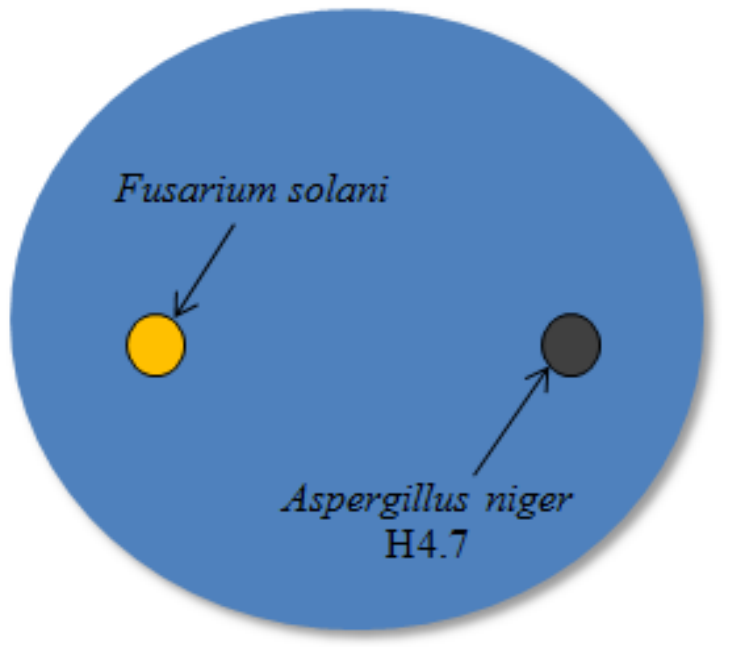

Hình 1. Sơ đồ bố trí khảo sát khả năng đối kháng của dòng nấm H4.7 với dòng nấm Fusarium solani gây bệnh thối rễ cây trồng trên môi trường PDA

\subsection{Phương pháp xử lý số liệu}

Số liệu thí nghiệm được tổng hợp, tính toán bằng phần mềm Microsoft Excel và kiểm định thống kê ANOVA bằng phần mềm Minitab 16.2.

\section{KẾT QUẢ VÀ THẢO LUẬN}

3.1. Ảnh hưởng của một số điều kiện môi trường nuôi cấy khác nhau lên khả năng hòa tan lân và sinh khối của dòng nấm H4.7 ở điều kiện phòng thí nghiệm

\subsubsection{Anh hương của pH môi trường nuôi cấy}

a. Khả năng hòa tan lân

Kết quả khảo sát khả năng hòa tan lân của dòng nấm Aspergillus niger $\mathrm{H} 4.7$ trong môi trường NBRIP lỏng ở các mức pH khác nhau sau 12 NNC 
được trình bày trong Hình 2. Nhìn chung, hàm lượng lân hòa tan bởi dòng nấm $\mathrm{H} 4.7$ trong môi trường nuôi cấy có các mức $\mathrm{pH}$ khác nhau thì khác nhau và khác biệt ý nghĩa thống kê khi so sánh với nhau $(\mathrm{p}<0,05)$ ở từng thời điểm thu mẫu. Đồng thời, hàm lượng lân hòa tan bởi nấm H4.7 tăng mạnh ở giai đoạn $0-10 \mathrm{NNC}$, đạt cao nhất ở ngày 10 và sau đó có xu hướng giảm nhẹ ở thời điểm 12 NNC. Nghiệm thức môi trường có $\mathrm{pH}=7$ hàm lượng lân hòa tan cao nhất ở tất cả các thời điểm thu mầu và cao hơn khác biệt ý nghĩa thống kê ở một số thời điểm thu mẫu với ba nghiệm thức còn lại $(\mathrm{pH}=3, \mathrm{pH}=5$ và $\mathrm{pH}=9)$. Tại thời điểm $1 \mathrm{NNC}$, hàm lượng lân hòa tan ở các nghiệm thức $(\mathrm{pH}=3, \mathrm{pH}=5, \mathrm{pH}=7$ và $\mathrm{pH}=9)$ lần lượt đạt $26,3 \mathrm{mg} / \mathrm{L} \mathrm{P}_{2} \mathrm{O}_{5}, 112 \mathrm{mg} / \mathrm{L} \mathrm{P}_{2} \mathrm{O}_{5}, 128 \mathrm{mg} / \mathrm{L} \mathrm{P}_{2} \mathrm{O}_{5}$ và $89,4 \mathrm{mg} / \mathrm{L} \mathrm{P}_{2} \mathrm{O}_{5}$ và các nghiệm thức này khác biệt ý nghĩa thống kê khi so sánh với nhau $(\mathrm{p}<0,05)$. Sau đó, hàm lượng lân hòa tan ở các nghiệm thức này tăng lên rất nhanh sau $3 \mathrm{NNC}$ với hàm lượng lân hòa tan đều lớn hơn $1.000 \mathrm{mg} / \mathrm{L} \mathrm{P}_{2} \mathrm{O}_{5}$. Ở thời điểm 5 $\mathrm{NNC}$, hàm lượng lân hòa tan ở nghiệm thức $\mathrm{pH}=5$ và $\mathrm{pH}=7$ lần lượt đạt $2.218 \mathrm{mg} / \mathrm{L} \mathrm{P}_{2} \mathrm{O}_{5}$ và 2.404 $\mathrm{mg} / \mathrm{L} \mathrm{P}_{2} \mathrm{O}_{5}$ cao hơn và khác biệt ý nghĩa thống kê $(\mathrm{p}<0,05)$ khi so sánh với hai nghiệm thức còn lại $(\mathrm{pH}=3$ và $\mathrm{pH}=9)$ và hai nghiệm thức này lần lượt đạt $1.673 \mathrm{mg} / \mathrm{L} \mathrm{P}_{2} \mathrm{O}_{5}$ và $1.727 \mathrm{mg} / \mathrm{L} \mathrm{P}_{2} \mathrm{O}_{5}$. Vào thời điểm $7 \mathrm{NNC}$, hai nghiệm thức $\mathrm{pH}=5$ và $\mathrm{pH}=7$ tiếp tục có hàm lượng lân hòa tan cao hơn hai nghiệm thức còn lại $(\mathrm{pH}=3$ và $\mathrm{pH}=9)$, tuy nhiên, không khác biệt thống kê khi so sánh với nhau $(\mathrm{p}>0,05)$. Cụ thể, ở nghiệm thức $\mathrm{pH}=7$, hàm lượng lân hòa tan cao nhất đạt $2.522 \mathrm{mg} / \mathrm{L} \mathrm{P}_{2} \mathrm{O}_{5}$; kế đến, nghiệm thức $\mathrm{pH}=5$ có hàm lượng lân hòa tan đạt $2.295 \mathrm{mg} / \mathrm{L} \mathrm{P}_{2} \mathrm{O}_{5}$ và sau cùng, nghiệm thức $\mathrm{pH}=3$ và $\mathrm{pH}=9$ có hàm lượng lân hòa tan lần lượt đạt $2.031 \mathrm{mg} / \mathrm{L}_{2} \mathrm{O}_{5}$ và $2.049 \mathrm{mg} / \mathrm{L}$ $\mathrm{P}_{2} \mathrm{O}_{5}$. Ở thời điểm $10 \mathrm{NNC}$, nghiệm thức $\mathrm{pH}=7$ là nghiệm thức có hàm lượng lân hòa tan cao nhất đạt $2.674 \mathrm{mg} / \mathrm{L} \mathrm{P}_{2} \mathrm{O}_{5}$, cao hơn và khác biệt ý nghĩa thống kê $(\mathrm{p}<0,05)$ khi so sánh với ba nghiệm thức còn lại $(\mathrm{pH}=3, \mathrm{pH}=5$ và $\mathrm{pH}=9)$, ba nghiệm thức này có hàm lượng lân hòa tan lần lượt đạt $2.464 \mathrm{mg} / \mathrm{L}$ $\mathrm{P}_{2} \mathrm{O}_{5}, 2.547 \mathrm{mg} / \mathrm{L} \mathrm{P}_{2} \mathrm{O}_{5}$ và $2.473 \mathrm{mg} / \mathrm{L} \mathrm{P}_{2} \mathrm{O}_{5}$, tuy nhiên, ba nghiệm thức này không khác biệt ý nghĩa thống kê khi so sánh với nhau $(\mathrm{p}>0,05)$. Tại thời điểm $12 \mathrm{NNC}$, hàm lượng lân hòa tan ở các nghiệm thức có xu hướng giảm dần. Cụ thể, hàm lượng lân hòa tan ở nghiệm thức $\mathrm{pH}=7$ đạt $2.486 \mathrm{mg} / \mathrm{L} \mathrm{P}_{2} \mathrm{O}_{5}$ cao nhất và khác biệt ý nghĩa thống kê $(\mathrm{p}<0,05)$ khi so sánh với ba nghiệm thức còn lại $(\mathrm{pH}=3, \mathrm{pH}=5$ và $\mathrm{pH}=9$ ) và các nghiệm thức này có hàm lượng lân hòa tan lần lượt đạt $2.190 \mathrm{mg} / \mathrm{L} \mathrm{P}_{2} \mathrm{O}_{5}, 2.396 \mathrm{mg} / \mathrm{L} \mathrm{P}_{2} \mathrm{O}_{5}$ và $2.273 \mathrm{mg} / \mathrm{L} \mathrm{P}_{2} \mathrm{O}_{5}$. Như vậy, đối với dòng nấm $\mathrm{H} 4.7, \mathrm{pH}=7$ của môi trường nuôi cấy lỏng NBRIP là $\mathrm{pH}$ tối ưu nhất để giúp dòng nấm này hòa tan lân tốt nhất. Kết quả này tương tự với kết quả nghiên cứu của Phạm Thị Ngọc Lan và Hoàng Dương Thu Hương (2014) cho thấy pH tối ưu cho hai dòng nấm Aspergillus sp. M33 và Aspergillus sp. M72 được phân lập từ đất vùng rễ của cây Giá và cây Đước sống ở đất ngập mặn Thừa Thiên Huế phân giải phosphate cao nhất ở pH từ 5,5-7. Mặt khác, kết quả nghiên cứu của Trần Thị Xuân Phương và ctv. (2017) cho thấy ở điều kiện $\mathrm{pH}$ 7-7,5 là điều kiện pH tối ưu nhất để ba chủng nấm Aspergillus sp. HX11, TV21 và TD21 phân lập từ đất trồng rau màu sinh trưởng, phát triển và hòa tan lân tốt nhất.

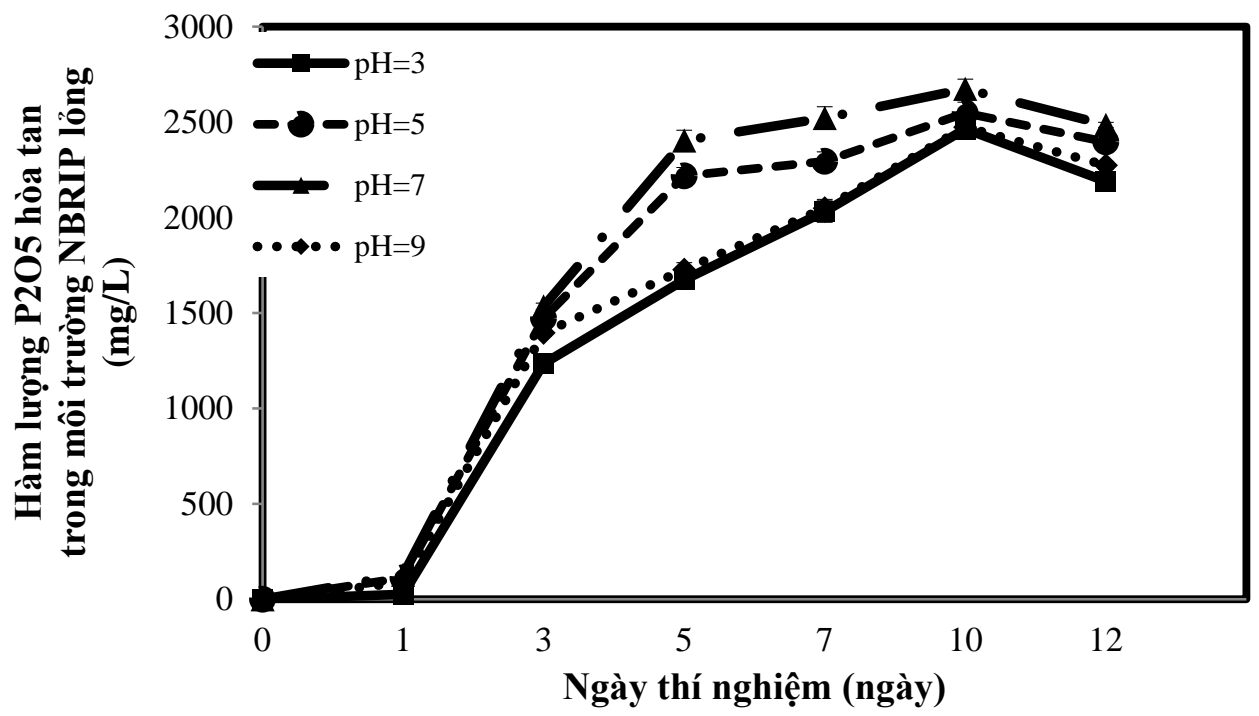

Hình 2. Khả năng hòa tan lân bởi dòng nấm H4.7 trong môi trường nuôi cấy NBRIP lỏng ở các mức pH khác nhau sau 12 NNC $(n=3$, độ lệch chuẩn $)$ 


\section{b. Sinh khối nấm}

Kết quả khảo sát ảnh hưởng của các mức $\mathrm{pH}$ môi trường nuôi cấy khác nhau lên sự hình thành sinh khối nấm Aspergillus niger $\mathrm{H} 4.7$ sau $12 \mathrm{NNC}$ được trình bày trong Hình 3 . Nhìn chung, dòng nấm $\mathrm{H} 4.7$ cho sinh khối cao nhất ở nghiệm thức môi trường NBRIP lỏng có $\mathrm{pH}=7$ với sinh khối đạt $10,9 \mathrm{mg} / \mathrm{mL}$ sau $12 \mathrm{NNC}$, cao hơn và khác biệt ý nghĩa thống kê $(\mathrm{p}<0,05)$ khi so sánh với các nghiệm thức còn lại, các nghiệm thức này dao động từ $6,77 \mathrm{mg} / \mathrm{mL}$ đển $9,13 \mathrm{mg} / \mathrm{mL}$. Kế đến nghiệm thức môi trường có $\mathrm{pH}=5$ cho sinh khối khô đạt $9,13 \mathrm{mg} / \mathrm{mL}$, cao hơn và khác biệt ý nghĩa thống kê với 2 nghiệm thức còn lại $\mathrm{pH}=3$ và $\mathrm{pH}=9$ ). Nghiệm thức $\mathrm{pH}=9$ có sinh khối đạt $8,75 \mathrm{mg} / \mathrm{mL}$, cao hơn và khác biệt ý nghĩa thống kê khi so sánh với nghiệm thức $\mathrm{pH}=3(6,77 \mathrm{mg} / \mathrm{mL})$. Các kết quả nghiên cứu trước đây cho thấy nấm thường tạo sinh khối tốt trong môi trường có $\mathrm{pH}$ từ 5-7 và ở mức $\mathrm{pH}$ này không gây ức chế sự phát triển của chúng (Nevarez et al., 2009; Wheeler et al., 1991). Tuy nhiên, nếu $\mathrm{pH}$ của môi trường thấp hơn 5 hay cao hơn 7 các dòng nấm có xu hướng phát triển và sinh trưởng chậm lại (Cao et al., 2007). Hơn nữa, sau 12 ngày bố trí thí nghiệm, nghiệm thức $\mathrm{pH}=7$ có $\mathrm{pH}$ môi trường đạt 5,76 . Điều này cho thấy quá trình hòa tan lân của nấm $\mathrm{H} 4.7$ có thể theo cơ chế sinh ra acid hữu cơ làm giảm $\mathrm{pH}$ môi trường ban đầu tạo điều kiện thuận lợi cho nấm $\mathrm{H} 4.7$ sinh trưởng và gia tăng sinh khối. Đồng thời, nghiên cứu của Fabia et al. (2014) cũng cho thây dòng nấm Aspergillus niger có khả năng tăng trưởng tối ưu trong môi trường $\mathrm{pH}$ dao động từ 4,0 đến 6,5 và theo nghiên cứu của Lê Thị Huệ (2010) pH môi trường quá thấp (khoảng 2-3) sẽ ngăn cản sự tạo thành bào tử, dẫn đến hệ sợi bị phân tán khi nuôi cấy chìm. Như vậy, kết quả nghiên cứu này cho thấy dòng nấm Aspergillus niger $\mathrm{H} 4.7$ sinh trưởng và phát triển sinh khối tốt ở điều kiện $\mathrm{pH}=7$ của môi trường bố trí thí nghiệm và mức $\mathrm{pH}$ này cũng giúp cho dòng nấm H4.7 hòa tan lân tốt nhất. Ngoài ra, khi so sánh giữa kết quả về sinh khối nấm với lượng lân hòa tan ở từng thời điểm thí nghiệm ở mục 3.1.1.1 cho thấy chúng có mối quan hệ chặt chẽ với nhau. Kết quả này cho thấy khi điều kiện môi trường nuôi cấy được tối ưu trong đó có $\mathrm{pH}$ môi trường sẽ giúp dòng nấm H4.7 phát triển sinh khối nhiều hơn và dẫn đến khả năng hòa tan lân của dòng nấm này tốt hơn.

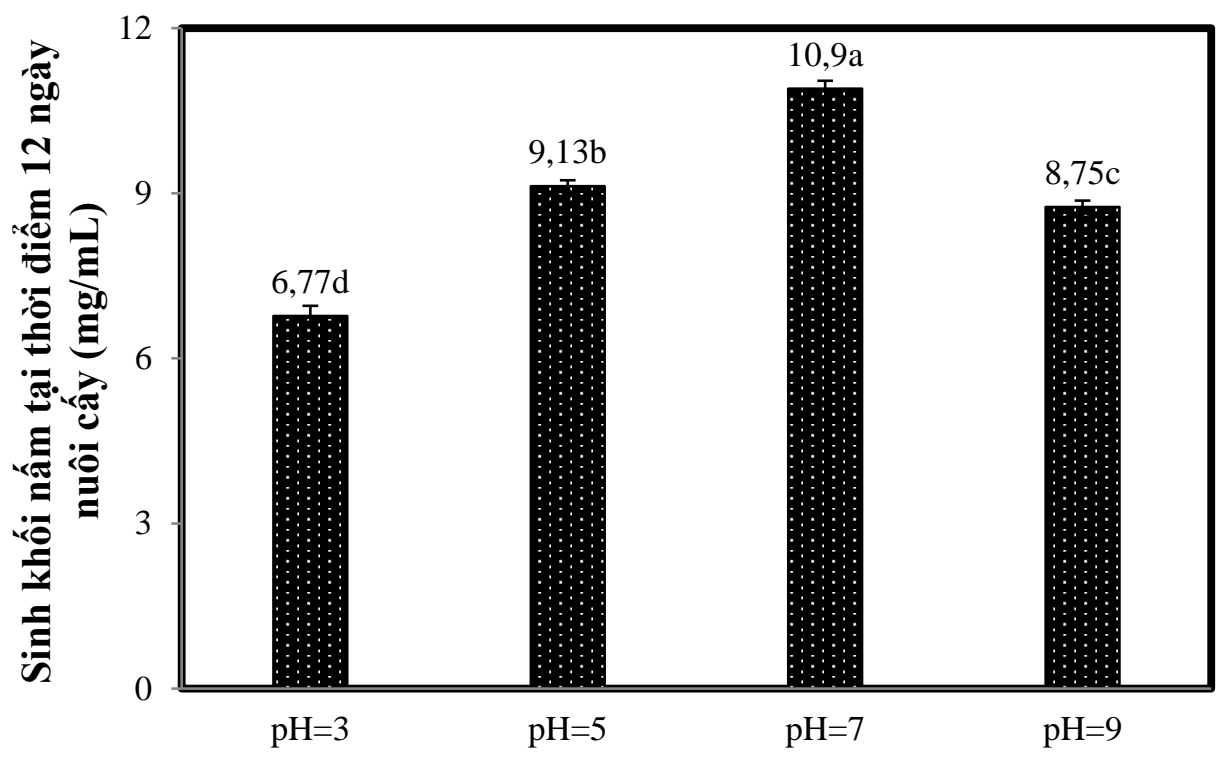

Các mức $\mathrm{pH}$ của môi trường nuôi cấy

Hình 3. Ảnh hưởng của các mức $\mathrm{pH}$ của môi trường nuôi cấy khác nhau đến sinh khối khô của dòng nấm H4.7 tại thời điểm 12 NNC $(n=3$, độ lệch chuẩn)

\subsubsection{Anh hưởng của nồng độ muối $\mathrm{NaCl}$ \\ a. Khả năng hòa tan lân}

Kết quả đánh giá ảnh hưởng của các nồng độ muối $\mathrm{NaCl}$ khác nhau trong môi trường nuôi cấy
NBRIP lỏng lên khả năng hòa tan lân của dòng nấm Aspergillus niger $\mathrm{H} 4.7$ sau $12 \mathrm{NNC}$ được trình bày ở Hình 4. Kết quả cho thấy trong dãy nồng độ muối $\mathrm{NaCl}$ khác nhau từ $0-10 \%$, dòng nấm $\mathrm{H} 4.7$ thể hiện khả năng hòa tan lân khác nhau. Hàm lượng lân hòa 
tan ở các thời điểm thu mẫu có sự khác biệt ý nghĩa thống kê khi so sánh giữa các nghiệm thức thí nghiệm với nhau $(\mathrm{p}<0,05)$ và tăng mạnh ở giai đoạn từ 1-5 NNC, ổn định ở giai đoạn 5-7 NNC, đạt cao nhất ở ngày 7 và giảm mạnh về sau. Nhìn chung, hàm lượng lân hòa tan bởi dòng nấm $\mathrm{H} 4.7$ giảm dần theo nồng độ muối tăng dần trong môi trường nuôi cấy NBRIP lỏng. Hàm lượng lân hòa tan giữa các nghiệm thức ở tất cả các thời điểm thu mẫu có thể được sắp xếp theo thứ tự như sau: $\mathrm{NaCl} 0 \%>\mathrm{NaCl}$ $1 \%>\mathrm{NaCl} 5 \%>\mathrm{NaCl} 10 \%$. Dòng nấm $\mathrm{H} 4.7$ có khả năng chịu đựng, sống sót và hòa tan lân đến môi trường nuôi cấy có nồng độ muối $\mathrm{NaCl} 10 \%$. Ở hầu hết các thời điểm thu mẫu, khả năng hòa tan lân của dòng nấm $\mathrm{H} 4.7$ tốt nhất ở nghiệm thức $\mathrm{NaCl} 0 \%$, tuy nhiên, vào các thời điểm 5,7 và $10 \mathrm{NNC}$, hai nghiệm thức $\mathrm{NaCl} 0 \%$ và $\mathrm{NaCl} 1 \%$ không khác biệt ý nghĩa thống kê về lượng lân hòa tan $(\mathrm{p}>0,05)$. Như vậy, dòng nấm $\mathrm{H} 4.7$ có khả năng phát triển và hòa tan lân tốt ở môi trường có nồng độ muối $\mathrm{NaCl}$ lên đến $1 \%$. Tuy nhiên, khi nồng độ muối $\mathrm{NaCl}$ được bổ sung cao hơn $1 \%$ sẽ dẫn đến việc làm giảm khả năng hòa hòa tan lân của dòng nấm H4.7. Như vậy, kết quả này cho thấy $0-1 \%$ là nồng độ mặn $\mathrm{NaCl}$ mà dòng nấm H4.7 có khả năng chịu đựng được để hòa tan lân tốt nhất. Kết quả này phù hợp với nghiên cứu của Phạm Thị Ngọc Lan và Hoàng Dương Thu Hương (2014) cho thấy dòng nấm Aspergillus sp. M33 hòa tan lân cao nhất ở nồng độ muối $\mathrm{NaCl}$ biến thiên trong khoảng $0,5-1,5 \%$, trong khi dòng nấm Aspergillus sp. M72 hòa tan lân cao nhất ở nồng độ muối $\mathrm{NaCl}$ nằm trong dãy $0,5-1,0 \%$.

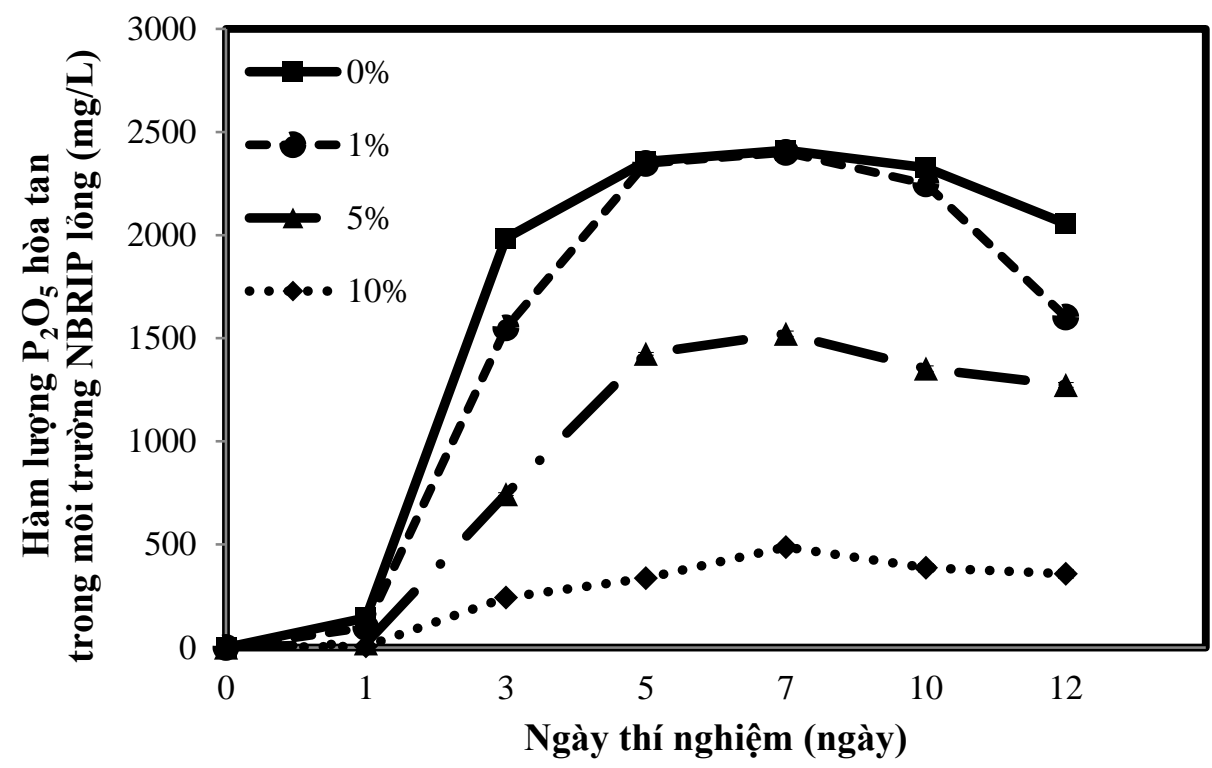

Hình 4. Khả năng hòa tan lân bởi dòng nấm H4.7 trong môi trường NBRIP lỏng bổ sung các nồng độ muối $\mathrm{NaCl}$ khác nhau sau 12 NNC $(\mathrm{n}=3$, độ lệch chuẩn $)$

\section{b. Sinh khối nấm}

Kết quả khảo sát ảnh hưởng của các nồng độ muối $\mathrm{NaCl}$ khác nhau trong môi trường nuôi cấy lên sinh khối của dòng nấm $\mathrm{H} 4.7$ sau $12 \mathrm{NNC}$ được trình bày trong Hình 5 . Nhìn chung, nồng độ muối $(\mathrm{NaCl})$ của môi trường nuôi cấy có ảnh hưởng đến sự tích lũy sinh khối của dòng nấm H4.7. Kết quả nghiên cứu cho thấy dòng nấm H4.7 có khả năng sinh trưởng, phát triển và tạo sinh khối trong môi trường nuôi cấy có nồng độ $\mathrm{NaCl}$ biến thiên trong khoảng $0-10 \%$. Nồng độ muối $\mathrm{NaCl}$ càng cao sẽ càng ức chế sự phát triển và hình thành sinh khối nấm. Cụ thể, sau 12 NNC ở điều kiện phòng thí nghiệm, nghiệm thức không bổ sung $\mathrm{NaCl}$ có sinh khối nấm cao nhất, đạt $17,1 \mathrm{mg} / \mathrm{mL}$, khác biệt ý nghĩa thống kê khi so sánh với các nghiệm thức còn lại $(\mathrm{p}<0,05)$, kế đến là nghiệm thức bổ sung $\mathrm{NaCl}$ $1 \%$ có sinh khối nấm cao thứ 2 , đạt $13,5 \mathrm{mg} / \mathrm{mL}$, cao hơn và khác biệt ý nghĩa thống kê khi so sánh với hai nghiệm thức còn lại $(\mathrm{p}<0,05)$. Thấp nhất là 2 nghiệm thức bổ sung $\mathrm{NaCl} 5 \%$ và $10 \%$, lần lượt đạt sinh khối $8,17 \mathrm{mg} / \mathrm{mL}$ và $8,11 \mathrm{mg} / \mathrm{mL}$, tuy nhiên hai nghiệm thức này không khác biệt ý nghĩa thống kê khi so sánh với nhau $(\mathrm{p}>0,05)$. Kết quả này phù hợp với kết quả nghiên cứu của Phạm Thị Ngọc Lan và Hoàng Dương Thu Hương (2014) cho thấy khả năng tích lũy sinh khối của dòng nấm Aspergillus sp. M33 tốt nhất ở môi trường nuôi cấy có bổ sung muối $\mathrm{NaCl}$ dao động từ $0,5-1,5 \%$. Đối với dòng nấm 
Aspergillus sp. M72, môi trường nuôi cấy có bổ sung $\mathrm{NaCl}$ với nồng độ dao động từ $0,5-1 \%$ là thích hợp nhất cho sự hình thành sinh khối nấm. Ngoài ra, khi so sánh sinh khối nấm với hàm lượng lân hòa tan ở các thời điểm thu mẫu cho thấy môi trường nuôi cấy nấm có vai trò quyết định rất lớn đến sự hình thành sinh khối nấm $\mathrm{H} 4.7$ và chính sinh khối nấm này quyết định đến khả năng hòa tan lân trong môi trường nuôi cấy. Tóm lại, dòng nấm Aspergillus niger $\mathrm{H} 4.7$ có khả năng hòa tan lân và cho sinh khối nấm cao nhất ở môi trường nuôi cấy không bổ sung $\mathrm{NaCl}$, tuy nhiên dòng nấm này có thể chịu đựng và sống sót được ở môi trường bổ sung $\mathrm{NaCl}$ lên đến $10 \%$. Ở các điều kiện mặn nhân tạo, dòng nấm H4.7 thể hiện khả năng hòa tan lân và cho sinh khối tốt nhất khi môi trường nuôi cấy bổ sung $\mathrm{NaCl} 1 \%$. Kết quả thí nghiệm này cho thấy dòng nấm $\mathrm{H} 4.7$ cho khả năng hòa tan lân ở hai nghiệm thức $0 \% \mathrm{NaCl}$ và $1 \%$ $\mathrm{NaCl}$ là tương đương nhau, tuy nhiên sinh khối nấm của hai nghiệm thức này là khác biệt thống kê khi so sánh với nhau $(\mathrm{p}<0,01)$. Điều này cho thấy ở mức độ mặn của môi trường nuôi cấy $1 \%$ là rất cao so với nồng độ mặn của đất nhiễm mặn, do đó một điểm đáng lưu ý của dòng nấm $\mathrm{H} 4.7$ này là ở nồng độ mặn $1 \%$ trong môi trường nôi cấy có ảnh hưởng một phần đến việc tạo sinh khối của nấm nhưng chức năng hòa tan lân của dòng nấm này không khác biệt thống kê khi so với nghiệm thức không bổ sung muối ( $0 \%$ $\mathrm{NaCl})$.

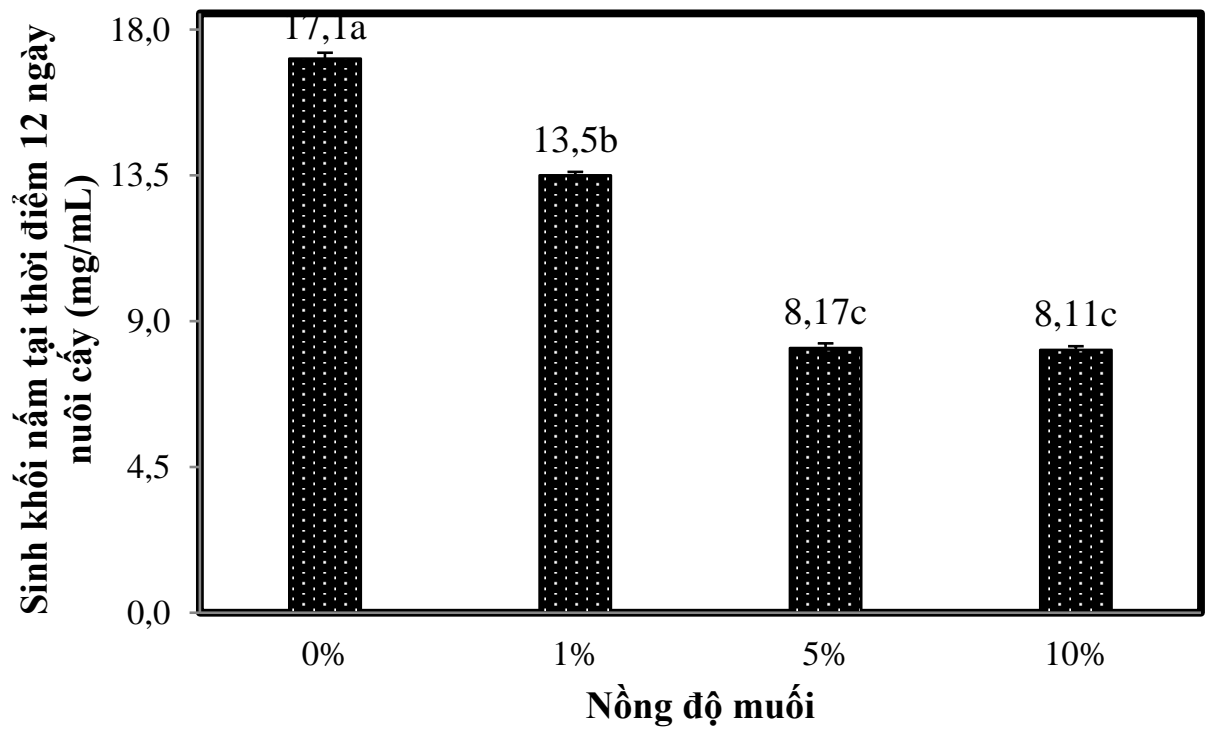

Hình 5. Ảnh hưởng của các nồng độ $\mathrm{NaCl}$ khác nhau đến sự sinh trưởng và phát triển của dòng nấm H4.7 tại thời điểm 12 NNC $(n=3$, độ lệch chuẩn)

\subsection{3. Đánh giá khả năng hòa tan hai dạng lân khó tan $\mathrm{FePO}_{4}$ và $\mathrm{AlPO}_{4}$}

\section{a. Khả năng hòa tan lân}

Kết quả khảo sát khả năng hòa tan lân $\mathrm{Ca}_{3}\left(\mathrm{PO}_{4}\right)_{2}$, $\mathrm{FePO}_{4}$ và $\mathrm{AlPO}_{4}$ bởi dòng nấm $\mathrm{H} 4.7$ trong môi trường nuôi cấy NBRIP lỏng sau $12 \mathrm{NNC}$ được trình bày trong Hình 6 . Kết quả cho thấy ở tất cả các thời điểm thu mẫu, dòng nấm $\mathrm{H} 4.7$ hòa tan lân dạng $\mathrm{Ca}_{3}\left(\mathrm{PO}_{4}\right)_{2}$ trong môi trường NBRIP lỏng cao nhất, kế đến là nghiệm thức chứa nguồn lân dạng $\mathrm{FePO}_{4}$ và sau cùng là nghiệm thức môi trường chứa lân dang $\mathrm{AlPO}_{4}$. Ở hầu hết các thời điểm khảo sát, có sự khác biệt ý nghĩa thống kê $(\mathrm{p}<0,05)$ được tìm thấy khi so sánh về lượng lân hòa tan trong môi trường nuôi cấy lỏng giữa 3 nghiệm thức thí nghiệm và hàm lượng lân hòa tan ở tất cả các thời điểm khảo sát có thể được sắp xếp theo thứ tự như sau: nghiệm thức bổ sung $\mathrm{Ca}_{3}\left(\mathrm{PO}_{4}\right)_{2}>$ nghiệm thức bổ sung $\mathrm{FePO}_{4}>$ nghiệm thức bổ sung $\mathrm{AlPO}_{4}$. Trong đó, ở nghiệm thức bổ sung nguồn lân $\mathrm{Ca}_{3}\left(\mathrm{PO}_{4}\right)_{2}$ dòng nấm $\mathrm{H} 4.7$ thể hiện khả năng hòa tan lân nhanh và mạnh nhất ở thời điểm 1-3 NNC, chậm lại ở giai đoạn 3-7 NNC, đạt cao nhất ở ngày 7 với giá trị lân hòa tan là 2.522 $\mathrm{mg} / \mathrm{L} \mathrm{P}_{2} \mathrm{O}_{5}$, sau đó giảm dần cho đến thời điểm kết thúc thí nghiệm. Kế đến, đối với nghiệm thức bổ sung $\mathrm{FePO}_{4}$, dòng nấm $\mathrm{H} 4.7$ hòa tan lân rất chậm ở giai đoạn 0-3 NNC, sau đó tăng mạnh ở giai đoạn 3$7 \mathrm{NNC}$, đạt cao nhất ở ngày 7 với hàm lượng lân hòa tan đạt $1.217 \mathrm{mg} / \mathrm{L}_{2} \mathrm{O}_{5}$ và sau đó giảm dần đến thời điểm kết thúc thí nghiệm. Cuối cùng, đối với nghiệm thức bổ sung nguồn lân $\mathrm{AlPO}_{4}$, dòng nấm $\mathrm{H} 4.7$ hòa 
tan lân rất chậm trong suốt thời gian thí nghiệm. Khả năng hòa tan lân dạng $\mathrm{AlPO}_{4}$ của dòng nấm $\mathrm{H} 4.7$ đạt cao nhất ở ngày 7 với giá trị $434 \mathrm{mg} / \mathrm{L}_{2} \mathrm{O}_{5}$, trong khi các ngày thu mẫu còn lại có giá trị lân hòa tan trong môi trường nuôi cấy thấp hơn và dao động trong khoảng từ $54,7 \mathrm{mg} / \mathrm{L} \mathrm{P}_{2} \mathrm{O}_{5}$ đến $410 \mathrm{mg} / \mathrm{L}$ $\mathrm{P}_{2} \mathrm{O}_{5}$.

Dòng nấm $\mathrm{H} 4.7$ hòa tan nguồn lân $\mathrm{Ca}_{3}\left(\mathrm{PO}_{4}\right)_{2}$ tốt hơn hai nguồn lân còn lại là $\mathrm{AlPO}_{4}$ và $\mathrm{FePO}_{4}$. Điều này có thể giải thích là do hai nguồn lân $\mathrm{AlPO}_{4}$ và $\mathrm{FePO}_{4}$ có cấu trúc hóa học phức tạp hơn so với nguồn lân $\mathrm{Ca}_{3}\left(\mathrm{PO}_{4}\right)_{2}$ (Mendes et al., 2014). Nhiều nghiên cứu trước đây cho thấy các dòng nấm phân lập thể hiện khả năng hòa tan lân thấp trong môi trường bổ sung hai dạng lân khó tan $\mathrm{AlPO}_{4}$ và $\mathrm{FePO}_{4}$ (Son et al., 2006; Zhang et al., 2018). Cơ chế hòa tan lân bởi vi sinh vật rất phức tạp, đa dạng và hầu như vẫn chưa được biết rõ. Tuy nhiên, cơ chế cơ bản và quen thuộc nhất là các tiến trình acid hóa, chelate và những phản ứng trao đổi (Chai et al., 2011). Ngoài ra, acid hữu cơ đóng vai trò quan trọng trong các tiến trình hòa tan lân của vi sinh vật trong đó có nấm, giúp phóng thích lân ra ngoài môi trường bằng cách cung cấp protons và tạo phức hợp anion hoặc những phản ứng trao đổi phối tử (ligand exchange reactions) hoặc tạo phức hợp với các ion kim loại để phóng thích lân ra dung dịch. Những sản phẩm acid hữu cơ được tạo trong thời gian nuôi cấy nấm phụ thuộc vào mối tương tác giữa nguồn lân đưa vào và nấm (Scervino et al., 2013; Zhang et al., 2018). Trong đất phèn chua, các oxit và hydroxit tự do của $\mathrm{Fe}$ và $\mathrm{Al}$ cố định $\mathrm{P}$, không giống như $\mathrm{Ca}$ trong đất kiềm (Ghosh et al., 2015). Nhìn chung, vi sinh vật hòa tan phosphate thể hiện khả năng hòa tan $\mathrm{P}$ tốt hơn trong môi trường chứa $\mathrm{Ca}_{3}\left(\mathrm{PO}_{4}\right)_{2}$, trong khi chúng thể hiện khả năng hòa tan $\mathrm{P}$ thấp trong môi trường chứa $\mathrm{FePO}_{4}$ và $\mathrm{AlPO}_{4}$ (Son et al., 2006). Mặc dù, khả năng hòa tan lân dạng $\mathrm{FePO}_{4}$ và $\mathrm{AlPO}_{4}$ bởi dòng nấm $\mathrm{H} 4.7$ thấp hơn nhiều so với dạng $\mathrm{Ca}_{3}\left(\mathrm{PO}_{4}\right)_{2}$ nhưng kết quả này cho thấy dòng nấm này có khả năng hòa tan được hai dạng lân khó tan trong đất, đặc biệt là vùng đất phèn nơi lân bị bất động chủ yếu dưới dạng $\mathrm{FePO}_{4}$ và $\mathrm{AlPO}_{4}$. Do đó, có thể ứng dụng dòng nấm Aspergillus niger $\mathrm{H} 4.7$ trong nghiên cứu này như dạng phân bón sinh học cho đất giúp chuyển hóa các dạng lân khó tan trong đất tạo thành các dạng lân hòa tan cho cây trồng dễ hấp thu, đồng thời còn cải thiện sự thiếu hụt lân trên nền đất phèn ở vùng Đồng bằng sông Cửu Long.

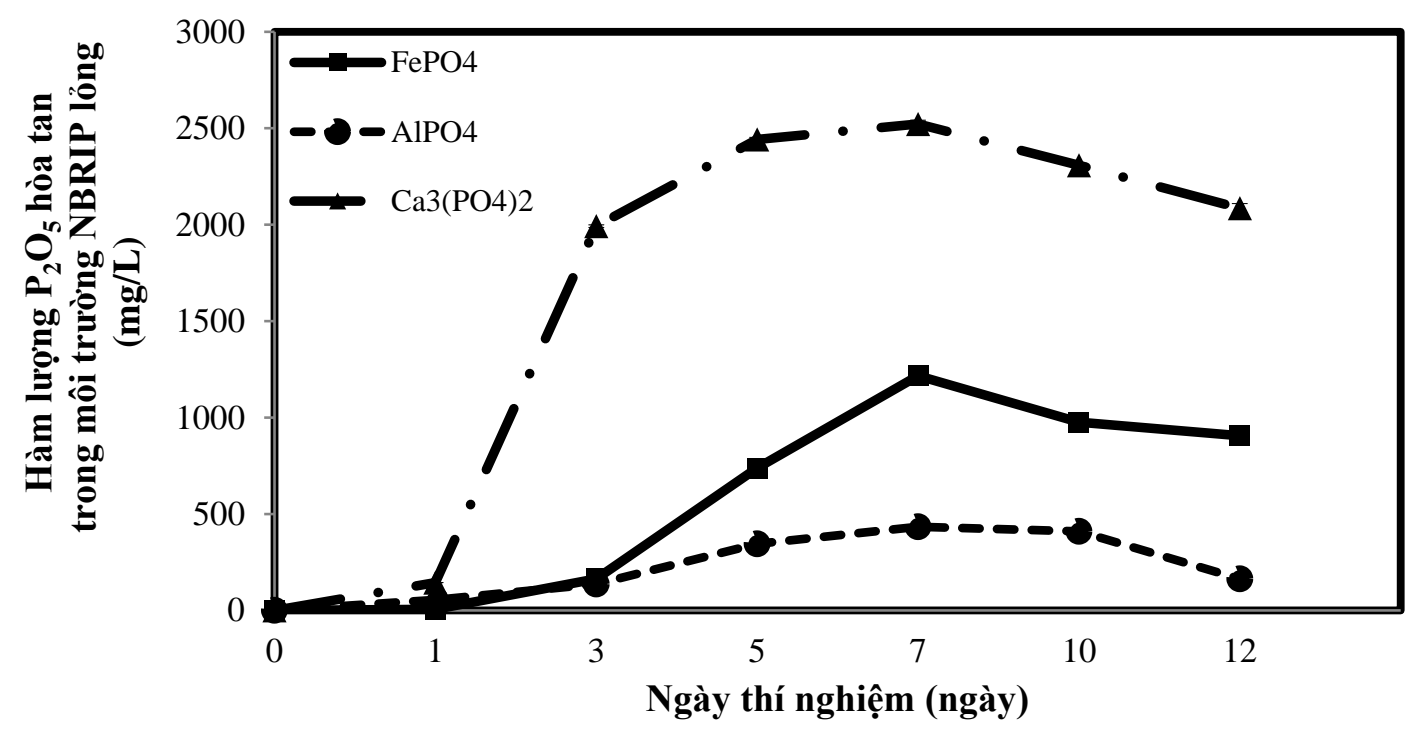

Hình 6. Khả năng hòa tan lân bởi dòng nấm H4.7 trong môi trường NBRIP lỏng bổ sung các nguồn lân khác nhau sau 12 NNC (n=3, độ lệch chuẩn)

\section{b. Sinh khối nấm}

Kết quả khảo sát sinh khối nấm Aspergillus niger $\mathrm{H} 4.7$ ở các nghiệm thức chứa các dạng lân khó tan khác nhau như: $\mathrm{Ca}_{3}\left(\mathrm{PO}_{4}\right)_{2}, \mathrm{FePO}_{4}$ và $\mathrm{AlPO}_{4}$ trong môi trường nuôi cấy NBRIP lỏng sau 12 NNC được trình bày ở Hình 7 . Kết quả nghiên cứu cho thấy khả năng tạo sinh khối của dòng nấm $\mathrm{H} 4.7$ là khác nhau trong môi trường NBRIP lỏng có chứa các dạng lân khó tan khác nhau $\left(\mathrm{Ca}_{3}\left(\mathrm{PO}_{4}\right)_{2}, \mathrm{FePO}_{4}\right.$ và $\left.\mathrm{AlPO}_{4}\right)$. Nghiệm thức môi trường nuôi cấy NBRIP bồ sung dạng lân $\mathrm{Ca}_{3}\left(\mathrm{PO}_{4}\right)_{2}$ cho kết quả về sinh khối dòng nấm Aspergillus niger $\mathrm{H} 4.7$ cao nhất, đạt $17,1 \mathrm{mg} / \mathrm{mL}$ và khác biệt ý nghĩa thống kê 
$(\mathrm{p}<0,05)$ khi so sánh với các nghiệm thức còn lại gồm nghiệm thức chứa $\mathrm{FePO}_{4}$ và $\mathrm{AlPO}_{4}$. Sinh khối nấm của hai nghiệm thức này lần lượt đạt 9,62 $\mathrm{mg} / \mathrm{mL}$ và $7,21 \mathrm{mg} / \mathrm{mL}$ và khác biệt ý nghĩa thống kê khi so sánh với nhau $(\mathrm{p}<0,05)$. Như vậy, dòng nấm hòa tan lân Aspergillus niger $\mathrm{H} 4.7$ tạo sinh khối tốt nhất trong môi trường nuôi cấy NBRIP lỏng chứa nguồn lân $\mathrm{Ca}_{3}\left(\mathrm{PO}_{4}\right)_{2}$, trong khi đó, ở môi trường nuôi cấy lỏng có chứa hai dạng lân khó tan còn lại như $\mathrm{FePO}_{4}$ và $\mathrm{AlPO}_{4}$, dòng nấm $\mathrm{H} 4.7$ tạo sinh khối rất ít. Như vậy, kết quả này cho thấy việc tạo sinh khối nấm trong môi trường nuôi cấy lỏng tùy thuộc vào lượng lân do nấm hòa tan được và lấy để tạo sinh khối nấm, từ đó, sinh khối nấm thực hiện chức năng hòa tan lân của mình. Kết quả khảo sát về mối quan hệ giữa sinh khối nấm và lượng lân hòa tan được trong môi trường nuôi cấy lỏng đã chứng minh cho điều này.

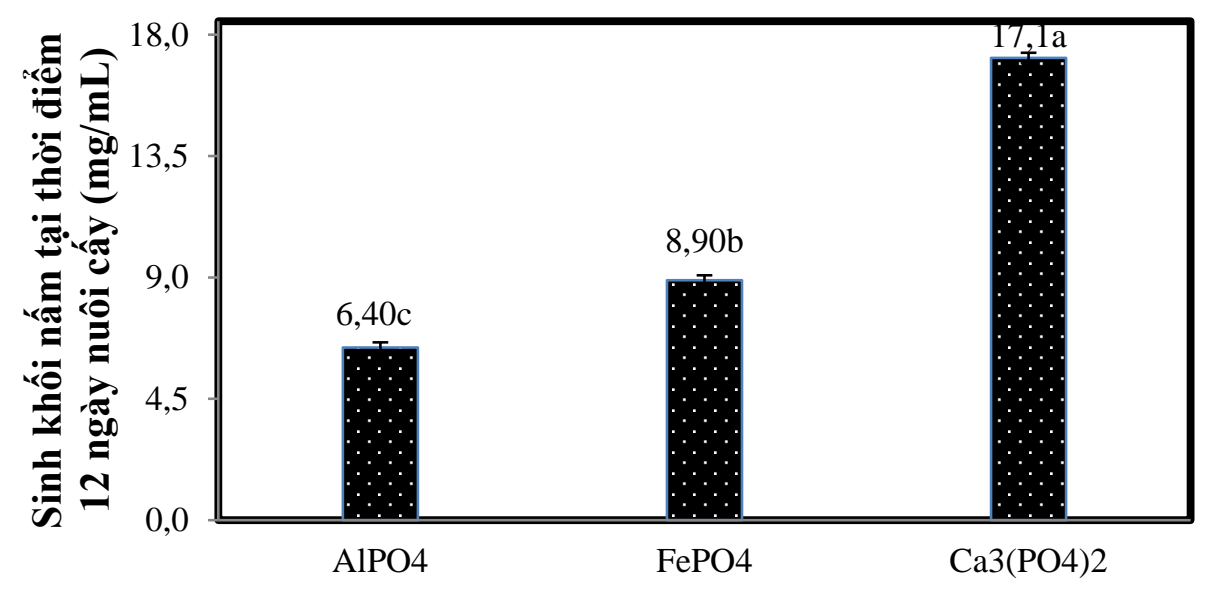

Các dạng lân khó tan

\section{Hình 7. Sinh khối nấm H.47 sau 12 NNC ở các nghiệm thức bổ sung nguồn lân khác nhau (n= 3, độ} lệch chuẩn)

\subsection{Khả năng đối kháng sinh học với dòng nấm Fusarium solani gây bệnh thối rễ cam sành của dòng nấm $\mathbf{H} 4.7$ ở điều kiện phòng thí nghiệm}

Kết quả khảo sát khả năng đối kháng sinh học của dòng nấm Aspergillus niger $\mathrm{H} 4.7$ với dòng nấm Fusarium solani được trình bày trong Hình 8 . Nhìn chung, dòng nấm hòa tan lân Aspergillus niger $\mathrm{H} 4.7$ thể hiện khả năng đối kháng tốt với dòng nấm Fusarium solani gây bệnh thối rễ cây trồng trong thời gian 7 ngày sau bố trí (NSBT) thí nghiệm. Ở thời điểm 1 NSBT, hiệu suất đối kháng với nấm bệnh của dòng nấm H4.7 36,5\% và tăng mạnh đến thời điểm 3 NSBT, đạt hiệu suất đối kháng 48,2\%. Đến thời điểm 5 NSBT, hiệu suất đối kháng của dòng nấm H4.7 đối với nấm bệnh Fusarium solani đạt 49,2\%. Sau đó, đến thời điểm 7 NSBT, dòng nấm $\mathrm{H} 4.7$ có hiệu suất đối kháng giảm xuống còn $48,9 \%$. Ở thời điểm này, sinh khối khuẩn ty của dòng nấm $\mathrm{H} 4.7$ đã phát triển kín đĩa và dòng nấm Fusarium solani hầu như không thể phát triển tiếp (Hình 10). Theo Nguyễn Thị Thu Nga (2003), nấm có khả năng hạn chế những vi sinh vật khác bằng các cơ chế như: tiết ra chất kháng sinh, cạnh tranh về dinh dưỡng, nơi ở ngoài ra còn hạn chế sự phát triển của nhóm vi sinh vật khác góp phần tạo sự cân bằng sinh thái trong tự nhiên. Kết quả khảo sát khả năng đối kháng thông qua chỉ số phần trăm đối kháng cho thấy dòng nấm $\mathrm{H} 4.7$ có hiệu quả ức chế dòng nấm Fusarium solani gây bệnh được thực hiện bởi nhiều cơ chế khác nhau và sử dụng cơ chế cạnh tranh nhiều hơn cơ chế tiết kháng sinh. Sự canh tranh này (bao gồm cạnh tranh dinh dưỡng, cạnh tranh nguồn sắt, không gian sống) có thể diễn ra theo nhiều cách như: gây ra những sự biến đổi bất thường trong hình thành bào tử, làm trương phòng sợi nấm, phá hủy hoặc làm hư hại các cấu trúc của sợi nấm hay tiết ra các enzyme để phân giải vách tế bào sợi nấm gây bệnh (Sharma, 2006). Nghiên cứu của Maria and Urszula (2012) cho thấy Aspergillus niger LOCK 62 có khả năng sản xuất enzyme chitinase cho hiệu quả kháng nấm gây bệnh. Enzyme chitinase được phân lập từ Aspergillus niger LOCK 62 có tiềm năng ức chế sự phát triển của các dòng nấm gây hại cây trồng như: Fusarium culmorum, Fusarium solani và Rhizoctonia solani. Hình ảnh ghi nhận từ thí nghiệm (Hình 9 và Hình 10) cho thấy dòng nấm H4.7 phát triển lan rộng về 
phía tản nấm gây bệnh làm sợi nấm không thể phát triển vượt qua được. Như vậy, kết quả nghiên cứu này cho thấy bên cạnh chức năng phân hủy tốt vật liệu hữu cơ từ phụ phế phẩm nông nghiệp, dòng nấm
H4.7 còn có chức năng hòa tan lân và đối kháng sinh học với dòng nấm Fusarium solani gây bệnh thối rễ cây cam sành. Do đó, có thể ứng dụng để làm phân bón vi sinh sử dụng cho đất và cây trồng.

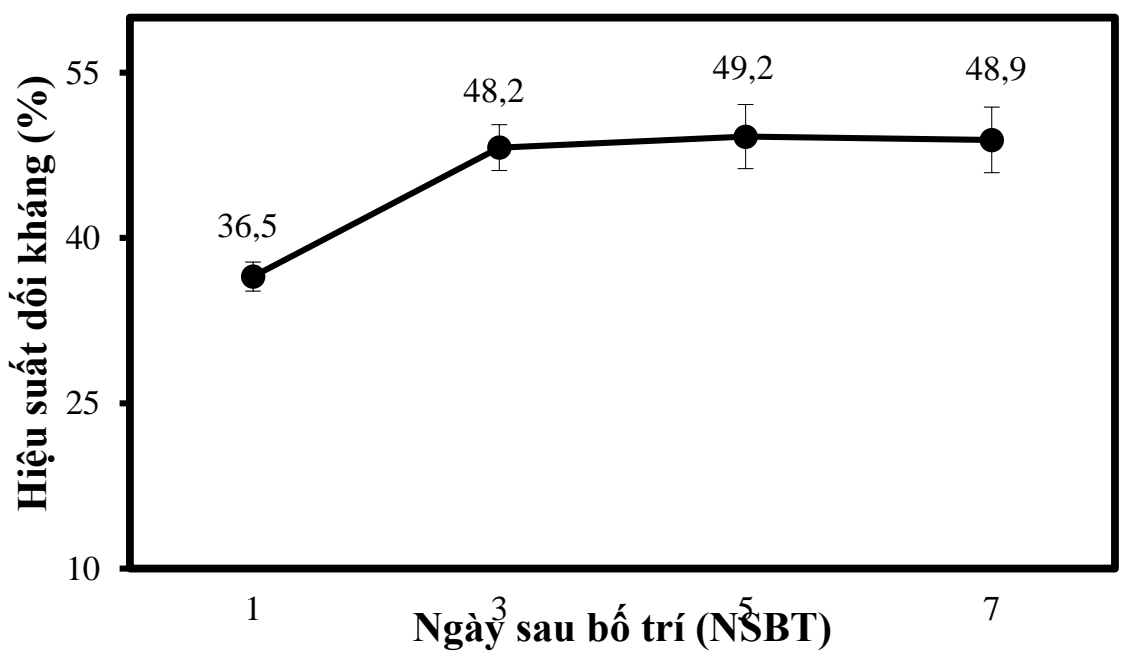

Hình 8. Hiệu suất đối kháng của dòng nấm H4.7 đối với dòng nấm Fusarium solani gây bệnh thối rễ cây cam sành trong 7 ngày bố trí thí nghiệm $(n=3$, độ lệch chuẩn)

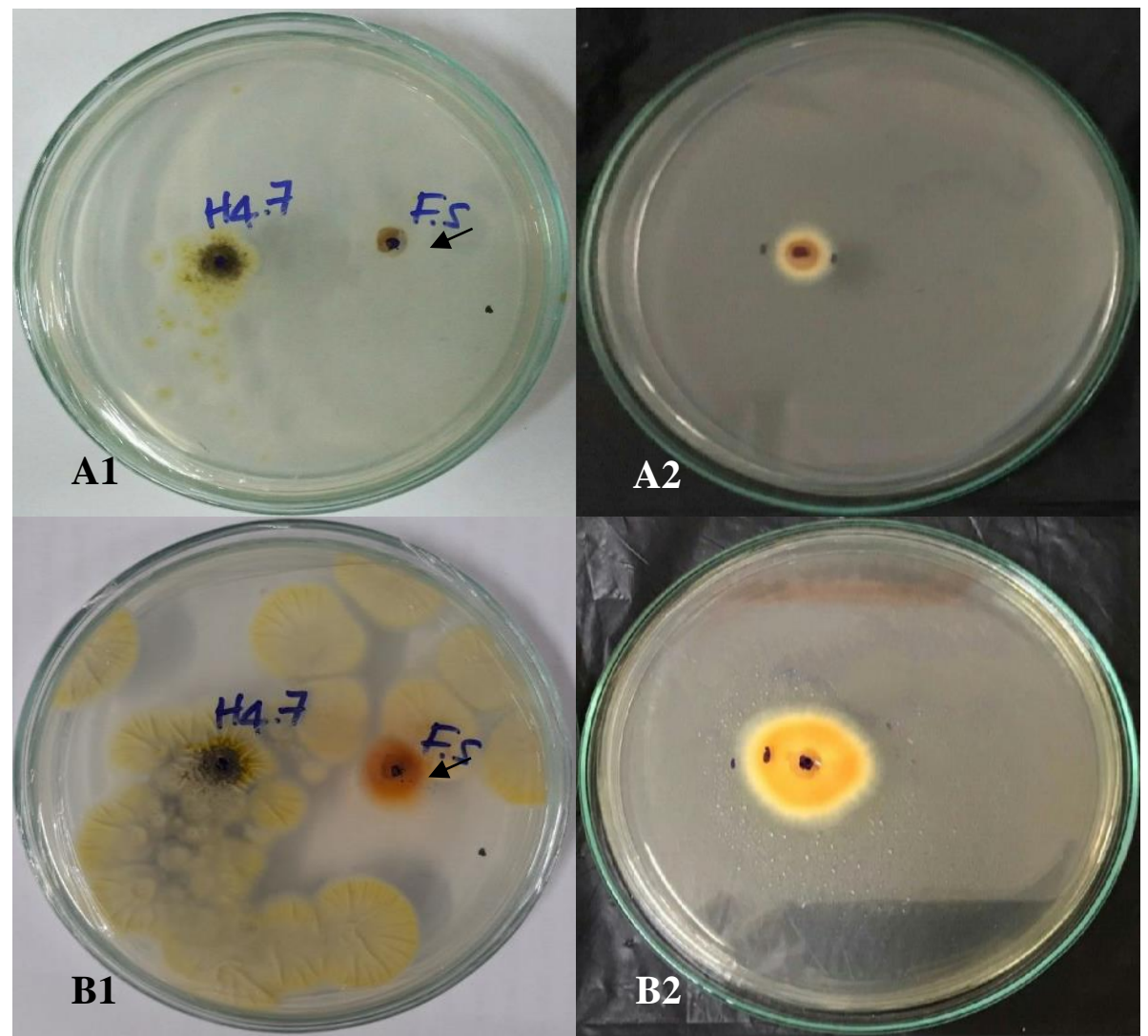

Hình 9. Hiệu quả ức chế của dòng nấm H4.7 đối với Fusarium solani và đối chứng Fusarium solani ở thời điểm 1 ngày sau bố trí ( $\mathrm{A} 1$ và $\mathrm{A} 2)$ và 3 ngày sau bố trí ( $\mathrm{B} 1$ và $\mathrm{B} 2)$ 


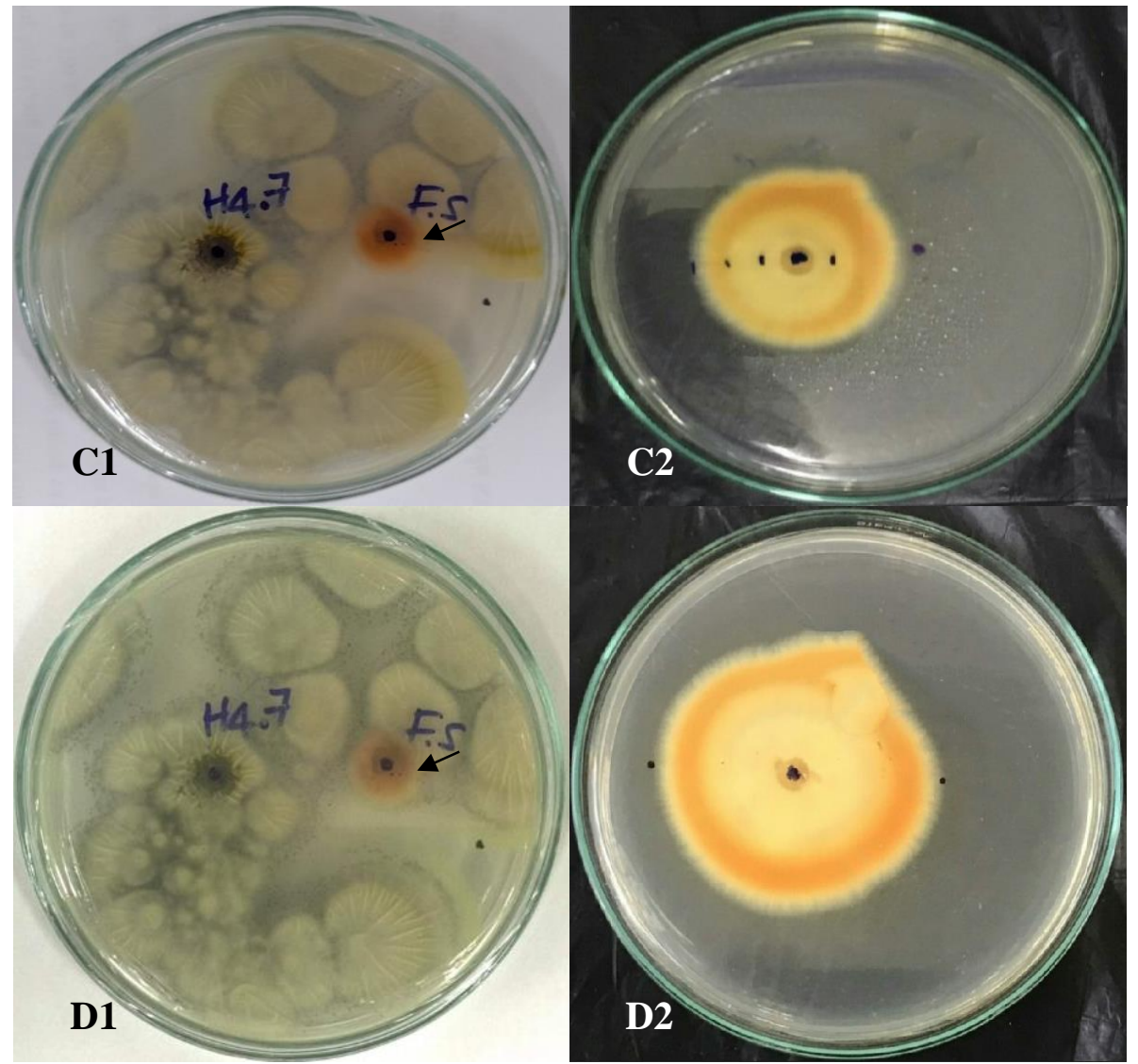

Hình 10. Hiệu quả ức chế của dòng nấm H4.7 đối với Fusarium solani và đối chứng Fusarium solani ở thời điểm 5 ngày sau bố trí $(\mathrm{C} 1$ và $\mathrm{C} 2)$ và 7 ngày sau bố trí (D1 và D2)

\section{KẾT LUẬN}

Dòng nấm Aspergillus niger H4.7 còn có chức năng hòa tan lân và đối kháng tốt với nấm Fusarium solani gây bệnh thối rễ cây cam sành. Ngoài ra, dòng nấm này còn hòa tan lân tốt nhất trong môi trường NBRIP bổ sung nguồn lân $\mathrm{Ca}_{3}\left(\mathrm{PO}_{4}\right)_{2}$, có $\mathrm{pH} 7$ và không bổ sung $\mathrm{NaCl}$. Dòng nấm $\mathrm{H} 4.7$ có khả năng chịu đựng và sống sót ở điều kiện môi trường bổ sung $\mathrm{NaCl} 10 \%$, tuy nhiên trong điều kiện bổ sung $\mathrm{NaCl}$, dòng nấm $\mathrm{H} 4.7$ thể hiện khả năng hòa tan lân tốt nhất và tương đương với nghiệm thức không bổ sung $\mathrm{NaCl}$ khi bổ sung $1 \% \mathrm{NaCl}$. Bên cạnh đó, dòng nấm $\mathrm{H} 4.7$ còn có khả năng hòa tan tốt hai dạng lân khó hòa tan khác gồm $\mathrm{FePO}_{4}$ và $\mathrm{AlPO}_{4}$. Do đó, dòng nấm Aspergillus niger $\mathrm{H} 4.7$ này có tiềm năng rất cao để sản xuất chế phẩm vi sinh có hiệu quả tốt trong hòa tan lân và đối kháng với nấm gây bệnh cây trồng giúp cải thiện dinh dưỡng và lân trong đất, đồng thời giúp giảm thiểu ô nhiễm môi trường do thuốc bảo vệ thực vật trong canh tác nông nghiệp ở các tỉnh thuộc khu vực Đồng bằng sông Cửu Long.

\section{TÀI LIỆU THAM KHẢO}

Asea, P. E. A., Kucey, R. M. N., \& Stewart, J. W. B. (1988). Inorganic phosphate solubilization by two Penicillium species in solution culture and soil. Soil Biology and Biochemistry, 20(4), 459464. https://doi.org/10.1016/00380717(88)90058-2.

Ashrafuzzaman, M., Hossen, F. A., Ismail, M. R., Hoque, A., Islam, M. Z., Shahidullah, S. M., \& Meon, S. (2009). Efficiency of plant growthpromoting rhizobacteria (PGPR) for the enhancement of rice growth. African Journal of Biotechnology, 8(7), 1247-1252. ISSN: 16845315.

Cao, C., Li, R., Wan, Z., Liu, W., Wang, X., Qiao, J., Wang, D., Bulmer, G., \& Calderone, R. (2007). The effects of temperature, $\mathrm{pH}$, and salinity on the growth and dimorphism of Penicillium marneffei. Medical Mycology, 45(5), 401-407. https://doi.org/10.1080/13693780701358600.

Chai, B., Yan, W., Pengming, L., Biao, L., \& Meiying, G. (2011). Isolation and phosphate solubilizing ability of a fungus, Penicillium sp. from soil of alummine. Journal of Basic 
Microbiology, 51(1), 5-14. https://doi.org/10.1002/jobm.201000192.

Fabiana, R. F. P., Thais, H., Noelly, A. L., Sabrina, C. B., Wilder, D. S., Maria das, G. C. \& Luis, R. B. (2014). Effect of temperature, water activity, and $\mathrm{pH}$ on growth and production of ochratoxin A by Aspergillus niger and Aspergillus carbonarius from Brazilian grapes. Journal of Food Protection, 77(11), 1947-1952. https://doi.org/ 10.4315/0362-028X.JFP-13-495.

Flavia, P. C., Wagner, P. F., \& Adriana, M. Y. M. (2012). Solubilization of phosphates in vitro by Aspergillus spp. and Penicillium spp. Ecological Engineering, 42, 85-89. https://doi.org/10.1016/j.ecoleng.2012.02.002.

Ghosh, P., Rathinasabapathi, B. \& Ma, L. Q. (2011). Arsenic-resistant bacteria solubilized arsenic in the growth media and increased growth of arsenic hyperaccumulat or Pteris vittata $L$. Bioresource Technology, 102(19), 8756-8761.

Ghosh, P., Rathinasabapathi, B., \& Ma, L. Q. (2015). Phosphorus solubilization and plant growth enhancement by arsenic-resistant bacteria. Chemosphere, 134, 1-6. https://doi.org/10.1016/j.chemosphere.2015.03.048.

Goldstein, A. (1994). Involvement of the quinoprotein glucose dehydrogenase in the solubilization of exogenous mineral phosphates by gram-negative bacteria. In: A. TorrianiGorini, E. Yagil and S. Silver, Eds., Phosphate in Microorganisms: Cellular and Molecular Biology, ASM Press, Washington DC, pp. 197-203.

Halder, A. K., Mishr, A. K., Bhattacharya, P. \& Chakrabarthy, P. K. (1990). Solubilization of rock phosphate by Rhizobium and Bradyrhizobium. Journal of General and Applied Microbiology, 36(2), 81-92. https://doi.org/10.2323/jgam.36.81.

Kannaiyan, S., Kumar, K., \& Govindarajan, K. (2004). Biofertilizer technology for rice based cropping system. Scientific Publishers (India), Jodhpur, 149-168. ISBN: 8172333595.

Khan, M. A., Tania, M., Zhang, D. Z., \& Chen, H. (2010). Antioxidant enzymes and cancers. Chinese Journal of Cancer Research, 22, 87-92.

Komy, M. H. E., Saleh, A. A., Eranthodi, A., \& Molan, Y.Y. (2015). Characterization of Novel Trichoderma asperellum Isolates to Select Effective Biocontrol Agents Against Tomato Fusarium Wilt. Plant Pathol Journal, 31(1), 50-60. https://doi.org/10.5423/PPJ.OA.09.2014.0087.

Lê Thị Huệ. (2010). Khảo sát khả năng sinh tổng hợp enzyme chitinase của một số chủng nấm sợi thuộc giống Aspergillus, Trichoderma và úng dụng. Luận văn Cao học chuyên ngành Sinh học. Trường Đại học Sư phạm thành phố Hồ Chí Minh.
Malboobi, M. A., Owlia, P., Behbahani, M., Sarokhani, E., Moradi, S., Yakhchali, B., Deljou, A., \& Morabbi, H. K. (2009). Solubilization of organic and inorganic phosphates by three highly efficient soil bacterial isolates. World Journal of Microbiology and Biotechnology, 25(8), 1471-1477.

Maria, S. B. \& Urszula, J. (2012). Production of Antifungal Chitinase by Aspergillus niger LOCK 62 and Its Potential Role in the Biological Control. Current Microbiol, 65(6), 666-672. https://doi.org/10.1007/s00284-012-0208-2.

Mendes, G. D. O., Freitas, A. L. M., Pereira, O. L., Silva, I. R., Vassilev, N. B., \& Costa, M. D. (2014). Mechanisms of phosphate solubilization by fungal isolates when exposed to different $\mathrm{P}$ sources. Annals of Microbiology, 64(1), 239-249.

Murphy, J., \& Riley, J. P. (1962). A modified single solution method for the determination of phosphate in natural waters. Analytica Chimica Acta, 27, 31-36. https://doi.org/10.1016/S00032670(00)88444-5.

Nahas, E. (1996). Factors determining rock phosphate solubilization by microorganism isolated from soil. World Journal of Microbiology and Biotechnology, 12, 18-23.

Nevarez, L., Vasseur, V., Le Madec, L., Le Bras, L., Coroller, L., \& Leguérinel, I. (2009).

Physiological traits of Penicillium glabrum strain LCP 08.5568, a filamentous fungus isolated from bottled aromatised mineral water. International Journal of Food Microbiology, 130(3), 166-171. https://doi.org/10.1016/j.ijfoodmicro.2009.01.013.

Nguyễn Hữu Hiệp \& Hà Danh Đức. (2009). Phân lập các dòng vi khuẩn cố định đạm và hòa tan lân cho đậu phộng trồng ở Trà Vinh. Tạp chí Khoa hoc Truờng Đại học Cần Tho, 11(b), 123-133.

Nguyễn Thị Thu Nga. (2003). Khảo sát khả năng đối kháng của vi khuẩn đối với nấm và tìm môi truờng nhân nuôi thích hơpp. Luận văn Đại học chuyên ngành Bảo vệ thực vật. Khoa Nông nghiệp. Trường Đại học Cần Thơ.

Novozamsky, I., Houba, V. J. G., Temminghoff, E., \& Van der Lee, J. J. (1984). Determination of 'total' $\mathrm{N}$ and 'total' $\mathrm{P}$ in a single soil digest. Netherlands Journal of Agricultural Science, 32(4), 322-324.

Phạm Thị Ngọc Lan \& Hoàng Dương Thu Hương. (2014). Nghiên cứu tuyển chọn chủng nấm mốc hòa tan phosphate vô cơ phân lập từ đất rừng ngập mặn ở Thừa Thiên Huế. Tạp chi Khoa hoc và Phát triển, 12(8), 1294-1301.

Quách Thị Trúc Ly. (2019). Khảo sát khả năng phân hủy cellulose của các dòng nấm phân lập tù đất nông nghiệp tỉnh Sóc Trăng. Luận văn Cao học chuyên ngành Sinh thái học. Khoa Khoa học Tự nhiên. Trường Đại học Cần Thơ. 
Reena, Dhanya, T., H. Deepthi, H., Pravitha, M. S., \& Lecturer, D. (2013). Isolation of phosphate solubilizing bacteria and fungi from rhizosphere soil from banana plants and its effect on the growth of Amaranthu cruentus L. Journal of Pharmacy and Biological Sciences, 5(3), 6-11. ISSN: 2278-3008.

Ruangsanka, S. (2014). Identification of phosphatesolubilizing fungi from asparagus rhizosphere as antagonist of root and crown rot pathogen, Fusarium oxysporum. Science Asia, 40(1), 16-20. DOI:10.2306/scienceasia15131874.2014.40.016.

Scervino, J. M., Mesa, M. P., Monica, I. D., Recchi, M., Moreno, S., \& Godeas, A. (2013). Soil fungal isolates produce different organic acid patterns involved in phosphate salts solubilization. Biology and Fertility of Soils, 49(6), 779-779.

Sharma, A., Mishra, M., Ram, K. R., Kumar, R., Abdin, M. Z. \& Chowdhuri, D. K. (2011). Transcriptome analysis provides insights for understanding the adverse effects of endosulfan in Drosophila melanogaster, 82(3), 370-376.

Sharma, P. D. (2006). Plant Pathology. Alpha Science International Ltd. Oxford.

Son, H. J., Park, G. T., Cha, M. S., \& Heo, M. S. (2006). Solubilization of insoluble inorganic phosphates by a novel salt- and $\mathrm{pH}-$ tolerant Pantoea agglomerans R-42 isolated from soybean rhizosphere. Bioresource Technology, 97(2), 204-210.
Sudhakara, R. M., Surender K., Babita, K., \& Reddy, M. S. (2002). Biosolubilization of poorly soluble rock phosphates by Aspergillus tubingensis and Aspergillus niger. Bioresource Technology, 84(2), 187-189.

Trần Thị Phương Thu \& Nguyễn Khởi Nghĩa. (2018). Phân lập và tuyển chọn một số dòng nấm hòa tan lân từ nền đất trồng lúa khô ngập xen kẽ kết hợp bón phân hữu cơ. Tạp chí Khoa hoc Trương Đại hoc Cần Tho, 54(9b), 23-33.

Trần Thị Xuân Phương, Nguyễn Thị Thu Thủy, Lê Xuân Diễm Ngọc, Nguyễn Lê Nhật Quang \& Võ Hoàng Minh Thu. (2017). Xác định điều kiện nuôi cấy tối ưu cho một số chủng nấm Aspergillus sp. phân giải phosphate vô cơ được phân lập trong đất trồng rau màu ở ThừaThiên Huế. Tạp chí Khoa họ và Công nghệ Nông nghiệp, Truờng Đại học Huế, 1(2), 337-344.

Wheeler, K. A., Hurdman, B. F., \& Pitt, J. I. (1991). Influence of $\mathrm{pH}$ on the growth of some toxigenic species of Aspergillus,

Penicillium and Fusarium. International Journal of Food Microbiology, 12(2-3), 141-149.

Zhang, Y., Chen, F. S., Wu, X. Q., Luan, F. G., Zang, L. P., Fang, X. M., Wan, S. Z., Hu, X. F., \& Ye, J. R. (2018). Isolation and characterization of two phosphate solubilizing fungi from rhizosphere soils of moso bamboo and their functional capacities when exposed to different phosphorus sources and $\mathrm{pH}$ environment. PLoS ONE, 13(7), https://doi.org/10.1371/journal.pone.0199625. 